\title{
BUSINESS BEHAVIOR OF TARIQA FOLLOWERS IN INDONESIA: The Relation of Religion, Sufism, and Work Ethic
}

\author{
Muhammad Djakfar
}

Universitas Islam Negeri Maulana Malik Ibrahim Malang

E-mail: mdjakfar@yahoo.co.id

\section{Abstract}

In Islam, people know a teaching and mystical practice called Sufism. Its main objective is to purify oneself (tazkiyat al-nafs) to get closer to God. Time-wise, Sufism can be mapped into orthodox and neo-Sufism. Teaching substance-wise, it is classified into akhlâqî and falsafî Sufism. So far, commoners and academician such as Max Weber believe that Sufism followers behave asceticly, live an austere life, have no capitalistic spirit, and so forth. This false perception obviously needs a correction for people understand the behavior of tariqa followers as an organized Sufism community among society. In Indonesia, tariqa followers include Sadziliyah and Shiddiqiyah. The basic question is if they live an austere life so they do not have to contribute to the economic life of nation. Result study shows that according to Sadziliyah people, wealth has spiritual, economic, and social meaning by centralizing business activities in houses and market. Meanwhile, Shiddiqiyah followers consider that wealth has spiritual, economic, social, cultural, and preached meaning in various efforts. Therefore, both tariqas teach a balance between spiritual (worship) and material obligations, ukhrâwiyah and dunyâwiyah obligations as taught by neo-Sufism. In addition, it shows a relationship among religion, Sufism, and work ethic. 
Dalam Islam dikenal semacam ajaran dan praktik mistik bernama Tasawuf. Tujuan utamanya adalah mensucikan diri (tazkiyah al-nafs) agar dekat dengan Tuhan. Dari aspek waktu, tasawuf dipetakan dalam tasawuf klasik (orthodoxs Sufism) dan model baru (neo-Sufism). Dari substansi ajarannya, ia diklasifikasikan menjadi tasawuf akhlâqî dan falsafî. Selama ini, masyarakat awam maupun akademisi seperti Max Weber mempunyai persepsi bahwa penganut tasawuf berperilaku asketis, anti keduniawian, tidak mempunyai semangat kapitalistik, dan sebagainya. Tentu tesis menyesatkan itu perlu dicarikan antitesisnya dengan memahami perilaku kaum tarekat sebagai komunitas tasawuf yang terorganisir di masyarakat. Di Indonesia, kaum tarekat yang dimaksud di sini ialah Sadziliyah dan Shiddiqiyah. Pertanyaan mendasar yang diungkap adalah apakah benar mereka bersikap zuhud, sehingga tidak perlu memberi kontribusi pada ekonomi bangsa? Hasil kajian menunjukkan, menurut kaum Sadziliyah, harta mengandung makna spiritual, ekonomi, dan sosial dengan menjadikan rumah dan pasar sebagai aktivitas bisnis. Sedangkan menurut Shiddiqiyah, harta memiliki makna spiritual, ekonomi, sosial, budaya, dan dakwah dengan berbagai jenis usaha. Dengan demikian, kedua tarekat mengajarkan keseimbangan antara kewajiban spiritual (ibadah) dengan material, kewajiban ukhrâwiyah dengan dunyâwiyah sebagaimana yang diajarkan dalam neo-Sufism, sekaligus juga menunjukkan ada relasi antara agama, tasawuf, dan etos kerja.

Keywords: business behavior; religion; Sufism; tariqa followers; work ethic

Received: September 14, 2018; Accepted: November 15, 2018

\section{Introduction}

The discourse tries to address the question of whether there is a relation among religion, Sufism, and work ethic. The three terms are quite popular among society, particularly academicians. However, it is not easy to explain the relation scientifically since each term has autonomic meaning.

The term religion generically means God's teaching in Islam known as divine teaching in the form of Quran and sunna of the Prophet Muhammad. Meanwhile, Sufism is often related to a teaching to purify oneself in order to get close to Allah. In other words, it is a media and process to prepare oneself to purify his/her soul and fix his/her heart by totally implementing all things done by the prophet (Sayyid Nûr 2000, 11). 
$\mathrm{He}$, the Holiest, therefore to get close to Him it has to be done with pure soul in order to achieve an intense chemistry between the Creator and His creatures. For example, by doing worship and praying (Q.S. al-Baqarah [2]: 186). Both terms are in transcendental spiritual domain oriented on hereafter life (ukhrâwî).

Work ethic simply means a working spirit motivated by certain factors to do an activity, for instance, business as one of sharia obligations in Islam. Hence, the Quran has many ayahs encouraging people to work and earn money (Ahmad 1995).

Related to the title of the discourse, to answer the question, it is not enough to use only an abstract normative theoretical perspective. It also needs the discussion based on applied practical perspective used by tariqa followers becoming phenomena in society nowadays. They are the followers of Sadziliyah Kudus and Shiddiqiyah Jombang who are developing and being organized.

As both individual and social creature, human physically needs clothes, food, and house. Furthermore, human mentally needs basic spiritual energy. The needs have to be fulfilled equally and it is impossible to ignore one's need. Ignoring it means sacrificing human dignity. It denies Islamic teaching which guides people to achieve a happy life physically and mentally, in the world and hereafter.

The impact of advanced science and technology brings many advantages and comforts to human life. However, it also has negative impact in sharia perspective. Luxurious life and hedonism are the examples of negative impact in the modern era which leads people into the boring materialistic world and encourages them to commit suicide. It proves that any material in the world cannot fulfill human basic need and thirst that is spiritual values.

Furthermore, in the middle of the materialistic luxurious modern era, people tend to worship materials and position. Nowadays, human success is measured with their wealth and position. The cult on the materials and position leads to permissive social relation and often leads to behavior which less appreciate wisdom values. In the future, this bad behavior unconsciously brings people to the hell (al-Ghazâlî n.d., 47).

In reality, some people do the opposite. They feel that they do not need worldly materials or position which is universally alluring for most people. The negative side of this extreme behavior is their intense involvement with spiritual world leads them to ignore worldly social 
matters. They prefer having a good moral in order to achieve heaven promised by God (al-Ghazâlî n.d., 47).

However, people should have a proportional balance between profane worldly matters and transcendental hereafter matters. At the beginning of Islam, Prophet Muhammad took care of the country and also ran some businesses to earn living cost for his family. Then, his companions and some people followed him. He is the role model that should be followed by all Muslims.

In addition, the teaching of Sufism develops in the digital revolution era. It can be seen from the development of tariqas around the world and particularly in Indonesia, which is one of the biggest Muslim countries in the world. It leads to a question of whether they only pursue their hereafter and ignore their worldly matters. If that is the case, we cannot blame the thesis of Max Weber stating that Islamic teaching is ascetic and less competitive in the economic field. This concern has been developing universally until now in the global era (Weber 2003).

The discussion about business behavior had also been viewed from different perspectives. In gender area, business behavior and economic development often became the hot issue. Some says that only men do responsible for earning income for the family while the women stay home. However, in Islam, there is no such a cliche statement. Islam has Moslems work or do business instead of depending on others (Yaqin 2015, 273).

Previous study on business behavior in the perspective of Madurese fruit traders was also conducted. The research shows that the traders are divided into two groups. The first group tend to ignore the rules of trading. They care only about profit that they do not think that ethics in trading is important. Meanwhile, another group is the opposite. They abide by the rules that trading must be done honestly. They state that trading is not always about profit but also about gaining God's merit (Djakfar 2007).

Recently some people change their paradigm. The tariqas are no longer alienating themselves from social and worldly matters. They start to think rationally and proportionally on the worldly and hereafter matters. They tried to prove that sufi will not disappear in the modernize and industrial era. The sufi scholars then reexamined the nature and the role of Sufism in contemporary context (Kim 2008). Sufism people, through number of tariqa, have been involved in so many areas of modernization. They involve in politics, economic, and other "modern" things. This shows how sufis are actually responsive toward the globalization of the world 
(Howell and Bruinessen 2007). In this article, the writer tries to discuss some tariqas perspectives on business behavior and how they are different in some aspects.

\section{Religion and Sufism: Relation and Source Aspect}

The big question is how the relationship between religion and Sufism is? Religion universally becomes a source of teaching in life, both in the world and hereafter, written in holy books. In Islam, the holy book is called Quran given to the Prophet Muhammad through Jibril. Muslims believe that Quran is a miracle which can be memorized and its authenticity is guaranteed. Memorizing Quran has been done since the era of the Prophet Muhammad by his companions to preserve Quran and also for their formal worship needs (Watt 1999, 54).

Related to the fact, the main objective of Quran is to awake the high and noble spiritual awareness in human, in their relation with God and nature called by theosophists as a religious experience (Iqbal 1966, 158). It justifies that Sufism in Islam is derived from divine teaching namely Quran.

In this matter, Sufism can be drawn as one of the implementations of Islamic teachings emphasizing on spiritual purification to get closer to God and to achieve the degree of insân kamîl. According to Seyyed Hossein Nasr, the practice of Sufism is an emulation or effort to compete and follow the life of the Prophet Muhammad in order to achieve ma'rifah on the message of Quran written in shahâdat, "No God (Ilâh) except Allah" (Valiuddin 1997, 13). For Sufism followers, they always want to follow and repeat the Prophet's experience of being closer to God, based on their capability (Madjid 2000, 262).

For them, Sufism is a method or approach by doing dhikr or remembering Allah in order to get close to Him. Many ayahs in Quran command human to always remember Allah (Q.S. al-Kahf [18]: 24; al-A'râf [7]: 201; al-Baqarah [2]: 152). The closeness to Allah for those who want to get close to Allah is written in ayah, "And when My servants ask you, $(\mathrm{O}$ Muhammad) concerning Me - indeed I am near" (Q.S. al-Baqarah [2]: 186). Another ayah states that "And $\mathrm{He}$ is with you wherever you are" (Q.S. alHadid [57]: 4). Furthermore, the teaching of spiritual purification in Islamic world develops into a tradition of an organized movement called tariqa (Siregar 2002, 337).

Some opinions state that the twelfth century is considered as the beginning of Sufism tariqa formation (Watt 1999, 151; Siregar 2002, 266), 
even though the foundation has been started since the life of the Prophet Muhammad as reflected in his lifestyle (Siregar 2002, 46). In the period of Makkah, for instance, Muhammad had developed his spiritual awareness guided by Allah (Siregar 2002, 46).

In other words, actually, Muhammad already had a deep mystical element even though the expression had not yet been developed (Watt 1999, 157). It is written in Quran surah al-Najm [53]: 11-13, al-Takwîr [81]: 22-23. Moreover, the sufi suggest surah al-Shams [91]: 8-9 and surah Yûsuf [12]: 53 as the verses related to morality and asceticism, which are the basic principles in Sufism (Siregar 2002, 48).

Those are some verses that play role as the sources of Sufism teaching in Islam that takes Quran (revelation) as the main foundation beside personal experience of the Prophet Muhammad and his close companions. Thus, it is inappropriate to say that Sufism teaching is derived from other than Islam, such as Persian, Hinduism, Nasrani, Greek's philosophy or others. It seems that this assumption is created merely by seeing the typology's similarities and the practice in certain things (Siregar 2002, 47).

Based on the explication above, we should be convinced that Islam is related to Sufism in which the primary source is God's revelation. Basically, Sufism is a form of expression in realizing the teaching of God's revelation emphasizing on the sacred soul with taqarrub ilâ Allâh (keep ourselves close to God by doing all the obligations required by the religion) and ma'rifat Allâh (understanding the God). Moreover, it is also essential to grow the best moral value before Allah and human beings (Siregar 2001, 57).

With the moral (akhlâq), a sufi will recognize, obey, purify, and always praise his God both in happiness and sadness (al-Qushayrî n.d., 285). Since God is the Divine or the Most Sacred (al-Qarḍâwî 1426 H), we should also purify or cleanse ourselves to get closer to Him.

Thus, academically, this teaching can be mainly categorized into two schools of Sufism namely sunnî and falsafî Sufism. Sunnî Sufism, also known as akhlâqi Sufism, is a form of Sufism that keeps itself tightly embraced by Quran and hadith. The figures of this Sufism are Hasan alBaṣrî, al-Muhâsibî, al-Qushayrî, and al-Ghazâlî. Meanwhile, falsafî Sufism is the one influenced by philosophy teaching. Some of the figures are Ibn 'Arabî and Ibn Sab'în (Anwar and Solihin 2004; Toriquddin 2007). 
In the next development, it is also categorized into orthodox Sufism (classic) and neo-Sufism. Others call this second category social Sufism that relates Sufism teaching to various social aspects (Syukur 2004). The one proposed the term "neo-Sufism" was Fazlur Rahman in his well-known book entitled Islam (Rahman 1979, 193; Azra 2013, 125). He said that neoSufism is a refined type of Sufism that has been detached from the ecstatic and metaphysics character, and it is already replaced with other constituents from the inference or proof of Islamic orthodoxy (Azra 2013, 126).

In other words, neo-Sufism tries to emphasize and amend the puritan original moral and self-control aspects in Sufism world by eliminating the extreme characteristics of deviated popular Sufism (Azra 2013, 126). Thus, the emphasis of the new model of Sufism is the sociomoral reconstruction from Muslim community unlike the former Sufism, which emphasizes more on individual than social aspects (Azra 2013, 126). It can also be a reform Sufism with the principles of orthodox Islam by diverting the central attention to the socio-moral reconstruction of the Muslim society (Siregar 2002, 314).

The main figure/notable of neo-Sufism in Indonesia is Hamka whose book was entitled Tasawuf Modern (Hamka 1990). It seems that this new model of Sufism has nowadays been followed by modern society in the middle of moral crisis because of the decreasing spiritual values as the effect of the development of sophisticated science and technology. Originally, tasawuf is a school of ethic that its main discussion is about morality (Irham and Basith 2018, 51). No wonder, some of neo-Sufism teaching implementations can be understood from the attitude of tariqa followers in fulfilling their daily needs that certainly require interaction with a wide society.

Therefore, al-Qushayrî, a reformation of Sufism figure, suggests Islamic followers cast away laziness and foolishness by making use of time executing the function of Caliphate as an effort to fulfill physical and spiritual needs very well. He also states that the real sufi is not the one alienated from humans' life activities, but they are still required to keep active among the society to do Islamic preaching and keep the society's prosperity (Siregar 2001, 315-316).

Furthermore, neo-Sufism followers always try to accommodate the inheritance of followers of Sufism that can be reconciled with orthodox Islam, particularly moral and dhikr technique or murâqabah to get close to Allah. This self-approach means to see and feel the presence of Allah 
through anwâr al-bașirah (eyes of the heart), direct encounter (wahdat asshuhûd) and ittihâd or manuggaling kawula gusti (the unification of human being and God through mortality) (Siregar 2002, 63).

In contrary, orthodox Sufism is individual (ecstatical-metaphysical/ mystical-philosophical) that almost has no concern on social matters (Siregar 2002, 314; Madjid 2000, 262). In a more open-minded way, it is associated with 'uzlah (living in seclusion) to worship to God.

\section{A Brief of Sufism Development in Indonesia}

Indonesia is well-known as a country with the biggest majority of Muslims in the world. In 2018, about 88 percent of an estimated 263 million people are Muslims. It leads to people's consideration that Indonesia is a Muslim Country. Among those Muslim population, most of them are known as quite fanatic followers of Shâfi'î madhhab (school of thought in fiqh). In Sufism matter, they are the followers of al-Ghazâlî, as associated with one of his monumental works, which is greatly famous in this century, entitled Ihyâa' 'Ulûm al-Dîn (reviving religious science) (Madjid 1997, 79).

Before experiencing the life of a sufi, al-Ghazâlî states that humans will be able to achieve their highest knowledge concerning God and other essential knowledge by using their intelligence or reasoning called al-'Aql alMustafad that is Acquired Intellect (Nasution 1996, v-vi). With this intellect, a human can have direct relationship with active intellect (angels) as the last level of transcendental system and the source of all knowledge (Nasution 1996, vi).

However, al-Ghazâlî eventually realizes that intelligence or reasoning will not be able to grab the abstract values but through al-dhawa (intuition). Clearly, the ability of reasoning is solely confined in grabbing the argumentative knowledge (al-ilm al-burhân̂े), while intuition is able to grab the truly believed knowledge (al'ilm al-yaqinî) (Nasution 1996, vi). This is the true reason why al-Ghazâli eventually plays a part in Sufism rather than philosophy that merely relies on the limited capability of reasoning.

Al-Ghazâlî's thought has never been far from anyone trying to understand Islam broadly and deeply (Madjid 1997, 79-80). It is because he is acknowledged as Hujjat al-Islâm, leader, and forerunner of Islam since his thinking is broad and deep both in philosophy and Sufism world. In Fiqh, for example, al-Ghazâlî believes in Shâfi'î madhhab, thus the name of this 
big thinker is inseparable from Islamic thinking and understanding in Indonesia, which are also based on Shâfi'î madhhab (Madjid 1997, 80). Sufistic world is no exception.

Therefore, since Shâfi'î madhhab's influence is becoming stronger, the Sufism taught in Islamic boarding school is sunnî which is based on alGhazâlî Sufism (Siregar 2002, 225). This is contrast with tariqa. The tariqas developed in Indonesia such as Qadiriyah, Naqsyabandiyah, Sammaniyah, Syattariyah, and Khalwitiyah acknowledge and teach al-fana concept although not all of them are similar to the teaching of Abû Yazîd al-Bustâmî (Siregar 2002, 226). Besides, there are still a lot of things that need to be identified, such as Khalidiyah and Rifaiyah (Siregar 2000, 269), Sadziliyah (Mu'tasim and Mulkan 1998), Shiddiqiyah (Munir 2012), Wahidiyah (Shofwan 2017), and Syahadatain (Rosyid 2018).

In line with the spiritual awareness of Islam followers, in reality, tariqa movement in Indonesia is developed and has many followers based on the culture of most Muslims in Indonesia. It is proven by the growing number of ribât (small fortification) spread in various parts of the country, particularly in Muslim enclaves.

\section{Sufism and Tariqa: The Relation of Murshid (Guide) and Students toward Tazkiyat al-Nafs}

The tradition of Sufism is derived from individual activity in spiritual aspect aiming to reach the complete level of human being. In a further development, this movement keeps growing and developing into an organized movement known as tariqa. Hence, several followers of big tariqas occurred such as Qadiriyyah, Naqsyabandiyyah, Chistiyyah (Valiuddin 1997, 14) and others like Rifa'iyyah (howling dervishes).

The root word of tariqa is derived from Arabic language that is tarîqah; it means walk, way, method, school, ism/doctrine, and others. Terminologically, tariqa is formulated as a system of mutual life in a spiritual aspect to achieve ma'rifat Allâh (knowing God). It is also as a collective effort for tazkiyat al-nafs (soul purificastion) to get closer to God called turuq al-ș̂fivah (Siregar 2002, 263). Self-purification (nafs) can only be achieved through self-restraint, hard work, and earnestness (mujâhadah) so that eventually one's soul can reach serenity (mutmainnah) (Valiuddin 1997, 48). However, each embedded sufi solely emphasizes on one aspect without 
denying other aspects since sufi's love ('ish $q$ ) is understood by sufis as the realization of gnosis aspect (ma'rifah) (Valiuddin 1997, 14).

Sufism alteration as practical and personal science into tariqa as an institution is seemly inseparable from Sufism teaching development itself. Hence, the more it is known by a wide society, the bigger the number of society interested in learning Sufism. They approach the Sufism authority holder to guide them. This is the true first contact or initial guidance of a teacher called murshid toward the students in tariqa tradition.

A teacher, furthermore, will responsible to formulate a system of Sufism learning containing various elements which eventually will be a distinct factor for tariqa teaching. Consequently, a variation of tariqa system, developed with different method, is inseparable despite dissimilar understanding and experience of each Sufism teacher as the pioneer of tariqa (Siregar 2002, 266). In other words, tariqa is basically a form of developed Sufism with certain variation under the specification given by a teacher (spiritual guide) to the students or followers (Anwar and Solihin 2004, 166).

In tariqa, the authority of the spiritual guide toward the members (followers) is dominant in building the characters. Hence, there must be deep and restrained relational pattern in the organization of tariqa during the journey of knowing God. In this case, preserving that relational pattern, the followers must be loyal to their teacher (spiritual guide). They are not allowed to argue even though they actually have different viewpoint (Siregar 2002, 270). Moreover, the followers have to save and govern the spiritual guide's honor, in life or even after his death (Siregar 2002, 270).

In addition, the followers have some main duties: 1) maintaining taqwâ; 2) performing spiritual practices to purify soul; 3) being wara (abstinence); 4) being associated with pious people and scholars; 5) having morals and ethics; 6) being efficient with time; 7) witnessing Allah in everything (murâqabah); 8) working sincerely; and 9) building up sensibility (qalb) and emptying heart from the 'pollution' of the world (Siregar 2002, 270).

Hence, the followers of tariqa have to attain the purity of heart by maintaining morals and ethics such as being sincere, having good manners, good relationship, and introspection. Through introspection, the purity of soul will be controlled and attain closeness to Allah. This cannot be separated from the guide from Shaykh to the followers. 


\section{Business, Spirituality, and Work Ethics}

Human as mono-dualistic creature involves both inner and outerself, body, and soul. Human's body (jism) needs nutrition in the form of food in order to grow and develop. They need clothes to protect them from hot or cold. Besides, they also need a place to take rest and protect them from various forms of interference that might occur at any time.

On the other hand, soul has different essentials. Basically, a human is not only a manhood and spiritual creature, but a creature with mind, heart, and lust. All potential devices need to be fostered and developed according to Sharia rules. This spiritual coaching is implemented through the path of Sufism by entering the world of tariqa, namely the spiritual world that can bring people to approach their God as the Creator.

The word spiritual derived from Latin spiritus which means something that gives life or vitality on the system. Spirituality here is considered as the improvement of the quality of life in the world by concerning the afterlife value. It is also essential to put us in a broader framework of meaning and purpose (Zohar and Marshall 2005, 63).

In the other opinion, spirituality is derived from adjective word spiritual. Its noun is spirit, derived from the Latin word spiritus which means "respire." Spirituality contains several meanings, such as living, having a sacred status, profane, and the latter is related to God as causa prima life (Hendrawan 2009, 18).

However, based on the research result, in relation to corporations in America, the meaning of spirituality has been developed. 1) Spirituality is personal, so that people do not have to be religious to become spiritual; 2) Spirituality is the basic belief in the existence of the great power that governs the universe; 3) Basically, humans live to do good manners; and 4) Spirituality is related to caring, hope, kindness, love, and optimism (Hendriawan 2009, 19).

The result of a research which is conducted by Mitroff and Denton about meaning is in line with Zohar and Marshall. They stated that corporation which has a concern about spiritual capital (SC) always has target and strategy under broader context of meaning. In addition, it also has introspection, guided by vision and mission, character, modest, and devotion (Zohar and Marshall 2009, 63-66).

Based on the above explanation, spirituality is an ability of selfmanagement to increase inner vitality, as well as capability to actively contribute for their wider surrounding. In Islam, spirituality cannot be 
separated from the afterlife. Even the world with everything on it will only be meaningful if it is directed to the achievement of the final goal (Nasution 1996, 203). Otherwise, it will turn to be a barrier to achieve lasting happiness that is ideal for every believer.

Islam emphasizes that the afterlife is far more important than the temporary life in the world and is only fleeting (Q.S. al-Duhâa [93]: 4). Life is actually an investment or an instrument to build the afterlife. Both lives must be balanced where one should not be ignored. Quran emphasizes that there is a balance between the material and the spiritual, between the afterlife and the world. This is what has been stated in Q.S. al-Jumu'ah [62]: 10-11 and al-Qașaș [28]:77.

This balance pattern has also been exemplified by the Messenger of Allah as mentioned in another part of this paper (Afzalurrahman 1997; Antonio 2007; Djakfar 2012). Human needs property as a means to worship and build an essential life in the hereafter, so the way to obtain it must be clean and used as needed (Hamka 1994), therefore tazkiyat al-nafs for a sufi is not tainted.

Meanwhile, according to Mochtar Buchori, work ethics are attitudes and paradigm of work, work habits possessed by a person, and a group of people or a nation (Buchori 2002, 6). Asy'ari states that work ethics is the intention, character and quality of inner life, moral and aesthetic style, and their inner condition. It is a fundamental characteristic of themselves and their world which is reflected in the real world (Djakfar 2012, 96).

Hence, work ethics for a Muslim is motivated by that basic skill, as well as the quality of Islamic life from the spirit of tawhid and expressed through good manners. The spirit has been achieved since the ancient time between human and God (Q.S. al-A'râf [7]: 172). Therefore, working has a value of worship that is not only glorious for the fellow human beings, but also for God. Moreover, Islam promotes work at the level of religious obligation (shar $\hat{\imath})$ by mentioning that work is consistently 50 times juxtaposed with the word faith.

Some verses of the Quran which emphasize the importance of work can be understood from Q.S. al-Baqarah [2]: 62 and 198; Q.S. al-Nisâ' [4]: 29 and 124; Q.S. al-An'âm [6]: 132; QS. al-Kahf [18]: 30; Q.S. al-Mu'minûn [23]:40; Q.S. Fâtir [35]: 29; Q.S. Fușșilat [41]: 46; Q.S. al-Najm [53]: 39-41; Q.S. al-Ṣaff [61]: 10; Q.S. al-Jumu'ah [62]: 10-11; al-Zalzalah [99]: 7-8; Q.S. al-Inshirâh [110]: 6-7 (Ahmad 1995). 
This is actually the theological basis of the work ethics in Islam that is filled with spiritual values when doing business (work). A Muslim businessman is not only motivated for the sake of worldly or dunyâwiyah, but also simultaneously for an afterlife or ukhrâwiyah interests.

\section{Business Behavior of Tariqa Members: Understanding Reality}

As what has been stated that tariqa is an institutionalized method or path to Sufism currently developed in modern society, such as Indonesia. Therefore, before understanding the reality of tariqa business behavior, it is necessary to state that the business behavior of tariqa discussed in this work only focuses on Sadziliyah (Kudus, Central Java) and Shiddiqiyah (Jombang, East Java) tariqa.

From these two schools of tariqa, the point of difference will be found, which is in relation with how they interpret their property and behavior in economics. Property is a necessity of life as a means to do good manners to others and to worship God. For this reason, the property needs to be sought legally, like doing business that is justified based on sharia. Therefore, working is part of the obligations in Islam as illustrated in the previous discussion.

In accordance with the Sadziliyah's followers, wealth is a tool or medium to get closer to Allah (taqarrub ila Allâh), because it helps humans to feel the pleasure that Allah has given in the world. In addition, there will be many opportunities to practice His teaching more perfectly than those who are not wealthy (Mu'tasim and Mulkan 1998; Djakfar 2015). For someone being able to give alms, as a muzakki, and to perform Hajj, they have to be rich. It is based on the statement of M. Syariq, the head of Sadziliyah Kudus saying that it is not true that tariqa followers cannot be rich, as long as they are generous due to their property, for instance, they like giving charity (Mu'tasim and Mulkan 1998).

However, according to Sufism, humans should not be controlled by their property to avoid being trapped into the so-called hubb al-dunyâ (love of wealth) (Mu'tasim and Mulkan 1998). Loving wealth is believed to ruin attitude and soul purity which are the goals for tariqa followers. A further effect caused by the love of the world is closing the eyes of heart (qalb) or ma'rifat bi Allâh, which is actually counterproductive to the teachings of Sufism universally. Therefore, based on the perspective of Sadziliyah followers, the property has a spiritual meaning of worship. In addition to 
the economic meaning which is to meet the needs of life for themselves and their families by working hard and social meaning which is a lot of care for others (Djakfar 2015).

It is a different with Shiddiqiyah followers who interpret the property more broadly than Sadziliyah followers do. In Shiddiqiyah's perspective, the property has at least five meanings such as spiritual, economic, social, cultural, and Islamic preaching (da'wah) (Munir 2012; Djakfar 2015). Thus, the difference between them is in the aspect of culture and Islamic preach. Spiritual wise, Shiddiqiyah refers to it as an instrument to maintain the value of monotheism/tawhîd. Hence, anyone who implements the meaning of the statement of tawhîd (lâ ilâha illa Allâh) will feel motivated to fight in the path of Allah known as jihâd fî sabîl Allâh (Munir 2012; Djakfar 2015). It is impossible for struggling in the path of Allah only by thinking, but somehow it must be supported by adequate finance.

Economic wise, Shiddiqiyah followers are supposed to be financially independent so they do not be a burden tp others, as well as to reflect the work ethic in Islam as cited before. By emphasizing an independent attitude, the tariqa followers are strictly prohibited for asking others in any form (Munir 2012). It is considered as a taboo principle to be violated.

Social wise, Shiddiqiyah followers are encouraged to care for others using wealth as implied in the teachings of united (manunggaling) faith and humanity which is often revealed by the teacher (Islamic guide) and leaders (khalifah) (Munir 2012). This meaning seems similar to the meaning believed by Syadziliyah's followers which is an expression of philanthropic teachings in Islam.

Then, the meaning of culture in owning wealth is summarized in the "S3"; silaturrahim (maintaining social relationship), santunan (donation), and sedekah (charity). This culture, according to Kiai Mochtar, should not be tainted. It is the motivation for Shiddiqiyah people to work hard not only by pursuing fortune but also by giving charity, being tolerant and strengthening relationships with each other as an expression of eastern culture (Munir 2012; Djakfar 2015). While Islamic preach/da'wah means the assets owned can be used as a means to convey the truth of Islamic Sharia to the wider community which has become the idealism of the Shiddiqiyah tariqa since established. 
Furthermore, how true is their economic behavior? By defining such meaningful assets, the followers of the Sadziliyah tariqa consider either their home or market as the most important place for economic activity. The house is not just a resting place for family, but also a center of industrial and spiritual (Mu'tasim and Mulkan 1998; Djakfar 2015). Hence, not only does a house function as a trading place (mu'âmalah), but also as a praying place.

Therefore, in business activities, they always strengthen spiritual support by praying and worshipping Allah by using the mosque as the center of their activities. Spiritual motivation is inseparable from the role of Islamic guide (murshid), so they believe that it is a gratitude to tariqa that they can succeed in running a business (Munir and Mulkan 1998). Thus, for them, tariqa is used as the most appropriate means to deal with an uncertain fate in the business world.

The Shiddiqiyah tariqa is considered unique compared to Sadziliyah, because its followers pursue various businesses ranging from hotels to small businesses, such as tea bags and honey. Their economic behavior can be understood in the way they look for property that is interpreted as a reflection of the fight in the path of Allah (jihâd) and worship without ignoring supernatural powers of prayer, especially Islamic guide/murshid prayer and parents (Munir 2012; Djakfar 2015).

Prayer is interpreted as a pillar of spiritual strength for humans so it is a part of the teachings and practices that must be applied in everyday life. In their point of view, work is practicing the teachings of the Sharia to achieve the true God's blessing as written on His destiny (Munir 2012; Djakfar 2015).

In the business context, in their opinion, S3 culture, in this case, is believed to be a means to strengthen relations among related parties. While charity is viewed to be able to bring blessed fortune (barakah), it refuses problems and more importantly, it maintains business. Because of this, S3 culture seems to be considered very principle, so the followers of Shiddiqiyah should not violate it.

That is the economic behavior of both tariqas in which the followers have basically practiced the teachings of neo-Sufism because they have balanced interests, world, and afterlife. This is the true Sharia which is taught and exemplified by the Messenger of Allah and his companions. 


\section{Conclusion}

Based on the description above, the tariqa opines that there is a high worldly work ethic neither monastic nor ascetic (zuhud) as perceived by some views as long as it is a worldly hate. This means as if there had been a paradigm shift from the individual towards the social direction of society, or from the classical Sufism practice (orthodox) to the new model Sufism (neoSufism). It can also be explained in reality that they follow the school of social Sufism.

The active involvement in the business world between both tariqas, Sadziliyah Kudus and Shiddiqiyah Jombang, shows an open-minded attitude to the outside world (the wider community), for example with consumers, buyers, customers, fellow business parties, and other related parties. This indicates that the tariqa life today is not only concerned with the life of worship which only focuses on the transcendental afterlife/ ukhrawwiyah interests, but also at the same time it is a balance with the interests of mortal life. It is the true teaching of Islam, as exemplified by the Messenger of Allah and his companions.

They realistically begin to understand that wealth is not something that must be hated and shunned, but it is a medium or means of investment to pursue happiness towards the eternal life. This is the true spirituality of energy as well as the ethos possessed by the tariqas which are not owned by the secularists. Eternal life is believed to be a continuation of temporary worldly life and consequently building the afterlife that needs to be preceded by building a good worldly life in all aspects of life according to the Sharia as well as in trade (mu'âmalah) as taught in Islam.

It is the relation of religion, Sufism, and work ethic which is reflected in the business behavior of the Sadziliyah and Shiddiqiyah tariqa in Indonesia as illustrated above. Religion which is the main source of Sufism encourages people to work hard in the world as an investment field to gain happiness in the hereafter.

\section{References}

Afzalurrahman. 1997. Muhammad sebagai Seorang Padagang. Trans. Dewi Nurjulianti et. al. Jakarta: Penerbit Yayasan Swarna Bhumy.

Ahmad, Mustaq. 1995. Business Ethics in Islam. Islamabad: The International of Islamic Institute. 
Antonio, Muhammad Syafii. 2007. Muhammad SAW The Super Leader Super Manager. Jakarta: Prophetic Leadership \& Tazkia Institute.

Anwar, Rosihan, and Mukhtar Solihin. 2004. Ilmu Tasawuf. Bandung: CV Pustaka Setia.

Azra, Azyumardi. 2013. Jaringan Ulama Timur Tengah dan Kepulauan Nusantara Abad XVII \& XVIII. Jakarta: Kencana Prenada Media Group.

Buchori, Mochtar. 2002. Penelitian Pendidikan dan Pendidikan Islam di Indonesia. Jakarta: IKIP Muhammadiyah.

Djakfar, Muhammad. 2015. Wacana Teologi Ekonomi Membumikan Titah Langit di Ranah Bisnis dalam Era Globalisdasi. Malang: UIN-Maliki Press.

Djakfar, Muhammad. 2007. "Religion, Work Ethics, and Business Attitude: A Case Study on the Meaning of Business Behavior of Madurese Fruit Traders in Malang." IJABS 16(2): 93-110.

al-Ghazâlî, Abû Hâmid. n.d. Ihyâ' 'Ulûm al-Dîn, Vol 3. Indonesia: Dâr alIṇyâ' al-Kutub al-'Arabiyah.

Hamka. 1990. Tasawuf Moderen. Jakarta: Pustaka Hidayah.

Hendrawan, Sanerya. 2009. Spiritual Management From Personal Enlightenment Towards God Corporate Governance. Bandung: Mizan.

Howell, J. D., and Bruinessen, M. van. 2007. "Introduction: Sufism and the 'modern' in Islam". In Sufism and the 'modern' in Islam, ed. M. van Bruinessen and J. D. Howell. London: Routledge, 3-18

Iqbal, Muhammad. 1966. The Reconstruction of the Religious Thought in Islam. Lahore: Institute of Islamic Culture.

Irham and Abdul Basith. 2018. "Revitalisasi Makna Guru dari Ajaran Tasawuf dalam Kerangka Pembentukan Karakter.” Ulul Albab: Jurnal Studi Islam 19(1): 44-68.

Kim, Heon-Cheol. 2008. "The Nature and Role of Sufism in Contemporary Islam: A Case Study of the Life, Thought and Teachings of Fethullah Gülen.” Dissertation. The Temple University, Philadelphia. 
Madjid, Nurcholish. 2000. Islam Doktrin dan Peradaban. Jakarta: Yayasan Wakaf Paramadina.

Madjid, Nurcholish. 1997. Kaki Langit Peradaban Islam. Jakarta: Paramadina.

Munir, Misbahul. 2012. "Rasionalitas dan Fenomena Makna Harta Studi Pada Tarekat Shiddiqiyah Jombang.” Dissertation. Universitas Brawijaya Malang.

Mu'tasim, Radjasa, and Abdul Munir Mulkan. 1998. Bisnis Kaum Sufi Studi Tarekat Dalam Masyarakat Industri. Yogyakarta: Pustaka Pelajar.

Nasution, Muhammad Yasir. 1996. Manusia Menurut Al-Ghazali. Jakarta: Srigunting.

al-Qarḍ̂wî, Yûsuf. 1426 H. Fuṣ̂l fî al'Aqîdah bayn al-Salaf wa al-Khalaf. Cairo: Maktabat Wahbah.

al-Qushayrî, Abû al-Qâsim. n.d. Risâlat al-Qushayriyah. Dâr al-Khayr.

Rahman, Fazlur. 1979. Islam. Chicago: Chicago University of Chicago Press.

Rosyid, Moh. 2018. "Mengidentifikasi Kemuktabarahan Tarekat Syahadatain.” Ulul Albab: Jurnal Studi Islam 19(1): 98-118.

Sayyid Nûr ibn Sayyid 'Alî. 2000. Al-Tașawwuf al-Shar'î. Beirut: Dâr al-Kutub al'Ilmiyyah.

Shofwan, Arif Muyazin. 2017. "Dakwah Sufistik KH. Abdoel Madjid Ma'roef Melalui Tarekat Wahidiyah.” Jurnal Smart: Studi Masyarakat, Religi, dan Tradisi 3(1): 91-104.

Siregar, A. Rivay. 2002. Tasawuf dari Sufisme Klasik Ke Neo-Sufisme. Jakarta: PT RajaGrafindo Persada.

Syukur, M. Amin. 2004. Tasawuf Sosial. Yogyakarta: Pustaka Pelajar.

Toriquddin, Moh. 2007. Akhlak Tasawuf. Malang: KJM Universitas Islam Negeri (UIN) Malang.

Valiuddin, Mir. 1997. Zikir EF Kontemplasi dalam Tasawuf. Trans. M.S. Nasrullah. Bandung: Pustaka Hidayah. 
Watt, William Montgomery. 1999. Islam, A Short History. USA: Oneworld Publication.

Weber, Max. 2003. Etika Protestan dan Semangat Kapitalisme. Trans. Yusup Priasudiarja. Jakarta: Pustaka Promethea.

Yaqin, Ainol. 2015. "Pandangan Al Quran Tentang Pembangunan Ekonomi Berbasis Kesetaraan Gender." Ulul Albab: Jurnal Studi Islam 16(2): 265-81.

Zohar, Danah, and Ian Marshall. 2005. Spiritual Capital: Memberdayakan SQ di Dunia Bisnis. Bandung: Mizan. 